\title{
Sonia BEHRENDT
}

Uniwersytet im. Adama Mickiewicza w Poznaniu

\section{POLSKA I ROSYJSKA RODZINA WYRAZÓW POCHODZAZCYCH OD PS. *RO̧KA. WYBRANE ZAGADNIENIA}

Od prasłowiańskiego leksemu *roka powstały w językach słowiańskich następujące wyrazy: scs $р \boldsymbol{\kappa} \kappa a$, białorus., ukr., ros. pyкá, bułg. pъкá, serb., chorw. pýкa, słń. róka, czes., słc. ruka, pol. ręka, głuż., dłuż. ruka (Черных 1999: 82; Фасмер 1987: 515). Większość języków słowiańskich, w tym również język rosyjski, utraciły odziedziczone z prasłowiańszczyzny samogłoski nosowe. $W$ języku rosyjskim denazalizacja samogłosek nosowych miała następujący przebieg: szeroka wymowa dawnego $e$ doprowadziła do przekształcenia tej głoski w $a$, natomiast podwyższenie artykulacyjne dawnej samogłoski $\varrho$ spowodowało, że zaczęto ją wymawiać jako $u$ (Rieger 1998: 26). W polszczyźnie nadal funkcjonują samogłoski nosowe, jednakże zakres ich używania różni się $\mathrm{w}$ stosunku do prasłowiańskiego pierwowzoru za sprawą procesów, które zaszły w języku staropolskim, a w rezultacie doprowadziły do tego, że krótką nosówkę wymawiano jako ę, a długą jako a (Kuraszkiewicz 1970: 80-82). Odziedziczony z prasłowiańszczyzny leksem *roka został zasymilowany w obu językach słowiańskich - polskim i rosyjskim i mimo dokonanych zmian fonetycznych nadal pod względem znaczeniowym wyraz ręka i pyкa są tożsame.

Źródłem materiału do analizy porównawczej rodzin wyrazów pochodzących od polskiego leksemu ręka oraz rosyjskiego pyкa są Słownik języka polskiego pod redakcją Mieczysława Szymczaka (Szymczak 1978-1981) oraz Словарь русского языка (znany wśród lingwistów jako Мальй академический словарь, w skrócie $M A C$ ) zredagowany przez Anastasiję Pietrowną Jewgieniewą (Евгеньева 1999). Oba dzieła leksykogra- 
ficzne zostały uznane za słowniki bazowe, ukazujące słownictwo różnych pół tematycznych z zakresu zarówno leksyki rodzimej, jak i zapożyczonej. Obydwa leksykony rejestrują po 80000 jednostek leksykalnych. Ponadto słowniki te powstały w II połowie XX wieku, dlatego też ukazują aktualny stan obu języków słowiańskich. Ze słownika języka rosyjskiego wyekscerpowano 143 wyrazy, których podstawą słowotwórczą był leksem pyкa, natomiast w słowniku Szymczaka odnotowano 90 wyrazów pochodzących od polskiego słowa ręka. Materiał badawczy, liczący łącznie 233 leksemy, notuje słowa przynależące do różnych części mowy. Są to:

- czasowniki, np.: заруиаться⿱1 ('zapewnić sobie'), nopyuamı ('polecać, powierzać'), doręczyć, poręczać;

- rzeczowniki, nр.: белоруика ('laluś, paniczek, delikatniś'), подруиник (historyzm 'wasal, lennik'), ręcznik, rękodzieło;

- przymiotniki, nр.: двуруиныц ('dwuręczny'), наруиныц ('ręczny'), poręczny, it odręczny;

- przysłówki, nр.: близоруко ('krótkowzrocznie'), собственноруино ('własnoręcznie'), ręcznie, zręcznie.

$\mathrm{W}$ materiale rosyjskojęzycznym zarejestrowano 78 wyrazów z rdzeniem -pyк- (55\% wyselekcjonowanej leksyki), które posiadają w polszczyźnie ekwiwalentne znaczenie (choć w języku polskim ekwiwalent znaczeniowy nie zawsze jest derywatem od ręka). W Słowniku języka polskiego odnotowano 43 leksemy $\mathrm{z}$ rdzeniem -ręk- (co stanowi ponad $48 \%$ zgromadzonego słownictwa), posiadające swój odpowiednik znaczeniowy w języku rosyjskim. Niezależnie od produktywności języków pod względem tworzenia leksyki, której podstawą jest słowo ręka bądź pyka, w obu językach słowiańskich wspólne słownictwo stanowi niemalże połowę wyekscerpowanego materiału. Przykładami leksyki wspólnej, tożsamej znaczeniowo, są następujące pary wyrazów: pol. ręka - ros. pyкa, pol. rączka - ros. pуикa, pol. rękopis - ros. pукопись, pol. zaręczać - ros. pyuamıcs, pol. wyręczyć - ros. вbıрyuumb. Przykładami słownictwa charakterystycznego dla języka rosyjskiego są takie leksemy, jak: авторуика ('wieczne pióro'), косорукость ('aplazja kości promieniowej'), наруиники ('kajdanki'), рукокриллье ('nietoperze', łac. Chiroptera). Wyrazami funkcjonującymi jedynie w polszczyźnie są np.: rękodzielnik, zręcznościowy, doręczyciel, ręcznik.

1 Objaśnianie znaczenia rosyjskojęzycznych słów: Mirowicz 1980. 
Zgromadzony na podstawie wskazanych słowników materiał, liczący łącznie 233 leksemy, daje podstawę do oglądu wielu szczegółowych problemów dotyczących polskiej i rosyjskiej rodziny wyrazów opartej na ps. podstawie ${ }^{*}$ rogka. Celem niniejszego artykułu, będącego rekonesansem badawczym, nie jest ich pełny opis, ale przedstawienie, na wybranych przykładach, dwóch zagadnień pokazujących istotniejsze różnice $\mathrm{w}$ zasobie leksykalnym polskiej i rosyjskiej rodziny wyrazowej oraz wskazanie ich systemowych i kulturowych uwarunkowań. Zaprezentowane więc zostaną znane językowi rosyjskiemu, a zasadniczo obce polszczyźnie skrótowce, czyli rzeczowniki powstałe przez skrócenie wyrażenia składającego się najczęściej z dwóch wyrazów, przy czym jeden z nich zawiera rdzeń - pyk-. Drugim zasygnalizowanym problemem będą te ekwiwalentne znaczeniowo pary, które tylko $\mathrm{w}$ jednym $\mathrm{z}$ uwzględnionych języków wyrażane są derywatem od ps. *ro̧ka, zaś przyczyn doboru leksemów danej pary można się dopatrywać w uwarunkowaniach kulturowych.

\section{SKRÓTOWCE}

Jedną z cech charakterystycznych języka rosyjskiego jest jego duża produktywność pod względem tworzenia skrótów i skrótowców, które nie tylko funkcjonują $\mathrm{w}$ języku potocznym, ale również pojawiają się jako hasła $\mathrm{w}$ wielu słownikach języka rosyjskiego. W wyekscerpowanym materiale odnotowano trzy skrótowce, są to: технорук (технический руководитель) оznaczający 'kierownika technicznego', политрук (политический руководитель) to 'osoba wojskowa, która kierowała pracami politycznymi w wojsku radzieckim', a słowo военрук (военный руководитель) mоżna przetłumaczyć jako 'instruktor wojskowy'. Przytoczone skrótowce powstały z połączenia części dwóch wyrazów wchodzących w skład wyrażenia o charakterze nominalnym. W każdym z nich komponent złożenia oznaczający przywódcę lub kierownika redukowany jest do morfemu pyк. Również przymiotniki wskazujące w wyrażeniu specjalizację danego kierownika skracane są do najmniejszej grupy fonemów niosących ze sobą określone znaczenie (техно-, полит-, воен-).

Potwierdzeniem faktu, iż $\mathrm{w}$ języku rosyjskim nadal $\mathrm{w}$ taki sposób tworzone są skrótowce, mogą stanowić dwa wyrazy, które nie zostały odnotowane w Словаре русского язылка, ale pojawiły się w formie haseł słow- 
nikowych w Орфографическом словаре zredagowanym przez W. W. Lopatina - leksykon ten rejestruje stan ruszczyzny z końca XX stulecia i początku XXI wieku. W tym słowniku zanotowano mianowicie formę худрук (художественный руководитель) оznaczającą 'kierownika artystycznego' і физрук (физкультурный руководитель) w znaczeniu 'instruktor sportowy lub nauczyciel wychowania fizycznego'.

Warto wspomnieć, iż w polszczyźnie, ale raczej w jej odmianie potocznej, zaadaptowano niektóre skrótowce (jako pożyczki rosyjskie), jak np. politruk. Wyraz ten, obecnie rzadziej już używany, ma charakter wyraźnie ocenny, deprecjonujący osobę tak nazywaną.

\section{SŁOWNICTWO UWARUNKOWANE KULTUROWO}

Najczęściej język rozumiany jest jako narzędzie komunikacyjne, służące do przekazywania różnorakich informacji. Zdaniem Janusza Anusiewicza warto spojrzeć na język jako twór kultury, który jednocześnie jest: „«utrwalaczem», rezerwuarem, przenośnikiem i przekaźnikiem treści kulturowych" (Anusiewicz 1991: 17). Istotne będzie również - według Anusiewicza:

opisanie [...] kulturowej funkcji języka, a mianowicie funkcji poznawczej, która określa sposób ujęcia rzeczywistości przez język i sposób dotarcia do niej. Język $\mathrm{w}$ tym sensie jest narzędziem i środkiem poznania rzeczywistości, że głównie poprzez język poznajemy rzeczywistość, doświadczamy jej, zaś kategorie języka są nie tylko pewnymi, wysoce sformalizowanymi i uogólnionymi obserwacjami empirycznymi i interpretacyjnymi rzeczywistości, ale również określonymi strukturami poznawczymi naszego intelektu (Anusiewicz 1991: 19).

W świetle tego cytatu istotne będzie spojrzenie na zgromadzony materiał leksykalny pod kątem uwarunkowań kulturowych, czyli jak za pośrednictwem leksemu ręka bądź pyкa zostaje opisana rzeczywistość w obu językach słowiańskich.

'Książka zawierająca zbiór podstawowych wiadomości z zakresu jakiejś nauki' (Doroszewski 1996-1997) w języku polskim nazywana jest podręcznikiem, a w języku rosyjskim jest to yиебник. Funkcjonujące w obu językach słowiańskich leksemy posiadają taki sam sufiks -nik, który może oznaczać przedmiot przystosowany do pewnej czynności. Podręcznik jest wyrazem pochodnym od słowa podręczny, czyli znajdujący się pod ręką. 
Natomiast rosyjskojęzyczny wyraz pochodzi od rzeczownika yueбa, oznaczającego 'naukę'. Etymologia wskazuje, iż yиебник to przedmiot służący do uczenia się, dlatego też można uznać, że rosyjska nazwa koresponduje z rzeczywistym przeznaczeniem przedmiotu.

„U samych źródeł polszczyzny - jak pisze Magdalena Pastuchowa odnajdujemy wiele leksemów, które choć utworzone z rodzimych morfemów o wyrazistych funkcjach, mają wartość semantyczną niebędącą sumą znaczeń tychże morfemów" (Pastuchowa 2007: 129). Przykładem wyrazu, powstałego na gruncie języka polskiego w dobie staropolskiej, którego podstawę słowotwórczą stanowi leksem ręka, jest słowo ręcznik.

Widoczne w polskojęzycznej nazwie wyraźne odwołanie do ręki umotywowane jest faktem, iż w XVI wieku mianem ręcznika nazywano m.in. kawałek płótna używany do wycieranie rąk po umyciu (Sł XVI: t. 36)). Wraz z upływem czasu doszło do rozszerzenia zastosowania tego przedmiotu, a więc i do rozszerzenia zakresu znaczeniowego, co spowodowało, że związek między nazwą a faktycznym przeznaczeniem ręcznika nie jest już tak oczywisty.

Słowo to jest interesujące w perspektywie porównawczej, gdyż w języku rosyjskim kawałek płótna służący do wycierania ciała po umyciu to полотенце. Wyraz ten wywodzi się od słowa полотно oznaczającego 'płótno'. Sufiks -uye stosowany jest do tworzenia deminutywnych form rzeczowników rodzaju nijakiego. Dlatego też nолотенце oznacza mały kawałek płótna o wyżej wspomnianej funkcji. Nazwy uwarunkowane kulturowo wskazują, iż w języku rosyjskim dominuje odwołanie do wielkości i tworzywa tego przedmiotu, natomiast w polszczyźnie widoczne są nawiązania do części ciała, która będzie go używała.

Zarówno w zachodniosłowiańskich, jak również we wschodniosłowiańskich kręgach kulturowych funkcjonuje zawód rękawicznika, który obecnie staje się coraz rzadziej wykonywaną profesją. Ta rzemieślnicza profesja w języku rosyjskim nazywana jest периатоиник. Rzeczowniki powstałe na gruncie języka polskiego i rosyjskiego zostały utworzone w sposób analogiczny i oba nazywają rzemieślnika, który wykonuje rękawiczki skórzane. Jednak w ruszczyźnie podstawą słowotwórczą tego wyrazu nie został rzadko używany leksem рукавищъ 'rękawice', a периатка 'rękawiczka' - pochodzący od staroruskiego wyrazu nıpcmamuuga 'rękawiczka' (Фасмер 1987: 248). Funkcjonujący w gwarach pskowskich leksem nьрстатица pochodzi od słowa nьpcmъ (Wątróbska 2012: 182) (w języku rosyjskim, po zaniku jerów, słowo to przybrało formę nepcm), który 
został odziedziczony z prasłowiańszczyzny (ps. *pŕstz: Boryś 2005), w obu językach wyraz ten oznacza 'palec'. A więc w języku polskim nazwa okrycia dłoni - rękawiczka - zbudowana została na podstawie wyrazu ręka ps. *rogka, zaś w języku rosyjskim odpowiadająca mu периатка pochodzi od ps. *pŕsţ, oznaczającego 'palec'.

Rosyjski rzeczownik близорукость można przetłumaczyć na język polski jako 'krótkowzroczność'. Pierwsze człony obu złożeń są synonimiczne, ponieważ według Słownika języka polskiego Witolda Doroszewskiego jednym ze znaczeń leksemu blisko (Doroszewski 1996-1997) jest pozostawanie $\mathrm{w}$ małej odległości, niedaleko w przestrzeni; podobnie słowo krótko (Doroszewski 1996-1997) oznacza, że coś jest w niewielkiej odległości, blisko. Reasumując, pola semantyczne obu wyrazów się ze sobą pokrywają, więc ukazują podobną relację w przestrzeni. Ponadto język rosyjski w słowie близорукость wzmacnia relację przestrzenną, ponieważ w przypadku tej wady wzroku wszystko powinno być w niedalekiej odległości od osoby cierpiącej na to schorzenia, aby mogła to dostrzec. Natomiast w polszczyźnie odwołano się bezpośrednio do zmysłu wzroku.

Polskim odpowiednikiem rosyjskiego wyrazu рукоплескания są oklaski. Wyraz funkcjonujący w polszczyźnie nawiązuje do wykonywania czynności, czyli klaskania, uderzania w dłonie, stanowiącego wyraz podziwu, uznania. Dosłownie rosyjski leksem można przetłumaczyć jako 'trzepotanie, łopotanie rękoma'. Taki sposób zestawienia dwóch funkcjonujących w języku rosyjskim wyrazów: pукa i плескать ukazuje, iż nowo powstały rzeczownik nie odwołuje się do warstwy dźwiękowej, jak to ma miejsce $w$ języku polskim, a do gestu oraz części ciała, która wykonuje daną czynność.

Kolejnym leksemem ukazującym uwarunkowania kulturowe jest рукомойник oznaczający w języku polskim umywalkę. Rosyjski wyraz składa się z dwóch rdzeni $p y \kappa-i-м o \breve{u}$-, pierwszy z nich nawiązuje do wyrazu ręka, a następny pochodzi od leksemu мойкa, który można przetłumaczyć jako 'mycie, zmywanie'. Za pomocą sufiksu -Huк w języku rosyjskim tworzone są rzeczowniki oznaczające zarówno pomieszczenie, jak również zbiornik przystosowany do czegoś. Reasumując, рукомойник to zbiornik przystosowany do mycia rąk. Nazwa, funkcjonująca w języku rosyjskim, w pełni oddaje rzeczywiste przeznaczenie przedmiotu znajdującego się w łazience. Natomiast w polszczyźnie słowo umywalka genetycznie wywodzi się od leksemu umywalnia, oznaczającego 'mebel, sprzęt lub pomieszczenie, w którym znajdują się przybory do mycia' (Doro- 
szewski 1996-1997). Według typologii Renaty Grzegorczykowej leksem umywalka można zakwalifikować do nazwy przedmiotu, który jest obiektem wykonywania czynności (Grzegorczykowa 1979: 42-43).

Ekwiwalentem polskiego wyrazu dwulicowiec jest rosyjskie двурушHuк. Słownik języka polskiego wskazuje, iż dwulicowiec to 'człowiek obłudny, fałszywy, hołdujący dwóm zasadom lub ideom' (Doroszewski: t. 2). W podobny sposób została skonstruowana definicja rosyjskiego odpowiednika w leksykonie Jewgieniewej. Według tego słownika двурушник to 'osoba, która pod maską oddania potajemnie działa na korzyść wrogiej strony'2. Pierwszy morfem występujący $\mathrm{w}$ obu wyrazach to $d w u-/ \partial b y-$, pochodzący od liczebnika dwa. Na tym etapie analizy słowotwórczej kończą się podobieństwa analizowanych wyrazów pod względem ich budowy w obu językach słowiańskich. Morfem -lic- odwołuje się do występującego w polszczyźnie leksemu lico, oznaczającego 'twarz, oblicze' lub 'zewnętrzną powierzchnię niektórych przedmiotów, ścian, brył budynków'. Natomiast w języku rosyjskim kolejnym członem tego compositum jest morfem -pyu- (uwzględniając nietypową alternacje $k: s z)$, wywodzący się od słowa pyкa. Sufiks -owiec w języku polskim i -нuк w języku rosyjskim służą do tworzenia kategorii nomina agentis. Reasumując, w polszczyźnie rzeczownik określający człowieka obłudnego, fałszywego, posiadającego dwa oblicza moralne, został zbudowany z liczebnika dwa i rzeczownika lico, zaś w rosyjskim do liczebnika два dodany został derywat od pука. W obu więc językach nazwy wyraźnie odwołują się do rzeczywistości pozajęzykowej, jednak kulturowe różnice w kształtowaniu obu pojęć pokazują zupełnie inną perspektywę: polski wyraz sugeruje występowanie dwóch odmiennych obliczy jednego człowieka, natomiast rosyjski leksem двурушник ukierunkowuje na działanie, co potwierdza również definicja słownikowa.

Podjęty przeze mnie temat jest jedynie sygnałem problemu. Ogląd przyjętych jako podstawa materiałowa leksykonów pokazał, iż oba języki słowiańskie dobrze zasymilowały wyraz stanowiący spuściznę prasłowiańską i na jego podstawie stworzyły liczne rodziny wyrazowe. Słownik języka polskiego Szymczaka zaświadcza, iż na gruncie języka polskiego powstało nieco mniej derywatów pochodzących od leksemu ręka (90 wyrazów) w porównaniu z zasobem leksemów rosyjskich powstałych od

2 Тот, кто под личиной преданности кому-, чему-л. тайно действует в пользу враждебной стороны (Евгеньева 1999). 
rzeczownika рука (143 wyrazy), notowanych przez słownik Jewgieniewej. Konsekwencją tego jest fakt niepełnej ekwiwalentności w zakresie omawianej leskyki w obu językach. Mimo różnic ilościowych, w grupie rosyjskojęzycznej 55\% derywatów od rzeczownika pyкa ma polskie odpowiedniki pochodne od rzeczownika ręka (a więc odsetek słownictwa wspólnego z perspektywy języka rosyjskiego wynosi 55\%). Z perspektywy języka polskiego tak rozumiane słownictwo wspólne stanowi 43\%. Analiza porównawcza dwu wybranych zagadnień szczegółowych wykazała zarówno morfologiczne (charakterystyczne dla języka rosyjskiego skrótowce), jak i uwarunkowane kulturowo różnice w kształtowaniu poszczególnych pojęć w języku polskim i rosyjskim. Ale poza sygnalizowanymi zagadnieniami polska i rosyjska rodzina wyrazów pochodnych od ps. *rokka, przynosi wiele innych ważnych problemów badawczych wartych odrębnej analizy, jak choćby kwestie związane $\mathrm{z}$ doborem prefiksów i sufiksów czy też pisownią łączną i rozłączną niektórych leksemów z elementem -ręk-, -pyk- występujących w obu językach słowiańskich. Te jednak kwestie wymagają dalszych szczegółowych analiz i ustaleń; mogą się stać przedmiotem odrębnego opracowania.

\section{WYKAZ SKRÓTÓW}

$$
\begin{array}{ll}
\text { scs } & \text { - staro-cerkiewno-słowiański } \\
\text { białorus. } & \text { - białoruski } \\
\text { ukr. } & - \text { ukraiński } \\
\text { ros. } & \text { - rosyjski } \\
\text { bułg. } & \text { - bułgarski } \\
\text { serb. } & \text { - serbski } \\
\text { chorw. } & \text { - chorwacki } \\
\text { słn. } & \text { - słoweński } \\
\text { czes. } & \text { - czeski } \\
\text { słc. } & \text { - słowacki } \\
\text { pol. } & \text { - polski } \\
\text { głuż. } & \text { - górnołużycki } \\
\text { dłuż. } & \text { - dolnołużycki } \\
\text { ps. } & \text { - prasłowiański }
\end{array}
$$

\section{CYTOWANA LITERATURA}

Anusiewicz J., 1991, Kulturowa teoria języka. Zarys problematyki, w: Język a Kultura. Podstawowe problemy i pojęcia, pod red. J. Anusiewicza i J. Bartmińskiego, t. 1, Wrocław. 
Boryś W., 2005, Słownik etymologiczny języka polskiego, Kraków.

Doroszewski W. [red.], 1958-1969, Słownik języka polskiego, t. 1-11, Warszawa.

Grzegorczykowa R., 1979, Nazwy wytworów / rezultatów / i obiektów czynności (nomina patientis), w: eadem, Zarys słowotwórstwa polskiego. Słowotwórstwo opisowe, Warszawa.

Knapik K., 2011, Myśliciel i myśliwy. Myśl i namysł. Dawne nominacje w polu pojęć epistemicznych, „Kwartalnik Językoznawczy”, nr 2.

Kuraszkiewicz W., 1970, Rozwój samogłosek nosowych, w: idem, Podstawowe wiadomości z gramatyki historycznej języka polskiego: $z$ wyborem tekstów staropolskich do ćwiczeń, Warszawa.

Mirowicz A. (et al.) 1980, Wielki słownik rosyjsko-polski, t. 1-2, Warszawa.

Pastuchowa M., 2007, Dlaczego słowotwórstwo leksykalistyczne? Ogląd faktów diachronicznych, "LingVaria” 2007, nr 2 (4).

Rieger J., 1998, Cechy typowo wschodniosłowiańskie, w: idem, Z dziejów języka rosyjskiego, Warszawa.

Sł XVI - Słownik polszczyzny XVI wieku, t. 36, Warszawa 2012.

Szymczak M. [red.], 1978-1981, Słownik języka polskiego, t. 1-3, Warszawa.

Wątróbska H., 2012, Słownik staro-cerkiewno-rusko-polski, Kraków.

Евгеньева А. П. [red.], 1999, Словарь русского языка в четьлех томах, т. 1-4, Москва [online - dostęp 24 października 2013: http://feb-web.ru/feb/mas / mas-abc/18/ma417209.htm].

Срезневский И. И., 1902, Материаль для словаря древнерусского язька по письменным памятникам, т. 2, Санктпетербург.

Фасмер М., 1987, Этимологический словарь русского языка, т. 3, Москва.

Черных П. Я., 1999, Историко-этимологический словарь современного русского языка, т. 2, Москва.

\section{THE POLISH AND RUSSIAN FAMILY OF WORDS COMING FROM PROTO-SLAVIC ${ }^{*} R O K A$. SELECTED ISSUES}

\section{Summary}

A purpose of this article is to compare Polish and Russian word families formed from the Proto-Slavic lexeme * roka. 90 derivatives whose word-formation basis is the lexeme hand have been excerpted from Dictionary of Polish Language edited by M. Szymczak whereas 143 words deriving from the Russian word pyka have been found in Словаре русского язика edited by A. P. Jewgieniewa. Despite quantitative differences, a number of common lexis in the Polish language group amounts to $48 \%$ whereas in the Russian group to $55 \%$. 
Apart from the statistics, the article focuses on two detailed issues in the scope of differences in shaping lexical resources of word families coming from Proto-Slavic ${ }^{*}$ rogka in the Polish and Russian languages. The first difference involves morphological distinctions resulting from inherent tendencies of the Russian language to create acronyms such as технорук, военрук that do not exist in the Polish language. The second difference discussed here are cultural conditionings which influenced the creation of lexical distinctions in both languages certified in such word pairs as: podręcznik [handbook] - уиебник, ręcznik [towel] - полотение, rękawicznik [glove maker] - периатоиник, krótkowzroczność [shortsightedness] - близорукость, oklaski [clapping] - рукоплескания, итушаlka [sink] - рукомойник, dwulicowiec [two-faced] - двурушник.

Key words: Russian language, Polish language, derivatives from Proto-Slavic *rogka, acronyms, cultural conditionings 